\title{
Kandungan Nitrat dan Fosfat dalam Air Pori dan Kolom Air Padang Lamun Perairan Prawean, Jepara
}

\author{
Eko Wardana Parsaulian Tampubolon*, Ria Azizah Tri Nuraini, Endang Supriyantini \\ Departemen IImu Kelautan, Fakultas Perikanan dan IImu Kelautan, Universitas Diponegoro \\ Jl. Prof H.Soedharto S H, Tembalang, Semarang, Jawa Tengah 50275 Indonesia \\ ${ }^{\star}$ Corresponding author, e-mail : ekowpt@student.undip.ac.id
}

\begin{abstract}
ABSTRAK: Secara alamiah konsentrasi zat hara dalam perairan bervariasi untuk masing-masing bentuk senyawanya, termasuk nitrat dan fosfat. Lamun berperan penting terhadap sumbangan nutrien di perairan dengan hasil dekomposisi serasah lamun oleh mikroorganisme pengurai. Fungsi sistem lamun terletak pada pemahaman faktor-faktor yang mengatur produksi dan dekomposisi bahan organik serta efisiensi daur nutrisi dalam sistemnya. Penelitian ini bertujuan untuk mengetahui kandungan nitrat dan fosfat air pori sedimen dan kolom air serta mengetahui jenis dan jumlah kerapatan lamun yang terdapat di perairan Pantai Prawean Bandengan Jepara. Metode penelitian ini menggunakan analisis deskriptif. Analisa kandungan nitrat menggunakan metode analisis SNI 06-6989.31-2005 dan fosfat menggunakan metode analisis BP2-MU-A-08. Pengamatan lamun menggunakan transek kuadrat $50 \times 50 \mathrm{~cm}$ menurut panduan LIPI. Kandungan nitrat air pori sedimen berkisar 1,85-2,82 mg/l, tergolong sedang. Sedangkan kandungan nitrat kolom air berkisar 0,63-1,09 mg/l, tergolong rendah. Kandungan fosfat pada air pori berkisar 0,09 $-0,15 \mathrm{mg} / \mathrm{l}$, tergolong sangat subur. Sedangkan kandungan fosfat kolom air berkisar $0,02-0,04$ $\mathrm{mg} / \mathrm{l}$, tergolong cukup subur. Jenis lamun yang ditemukan pada lokasi penelitian sebanyak 4 spesies yaitu Enhalus accoroides, Thalassia hemprichii, Cymodocea serullata, dan Cymodocea rotundata. Kerapatan lamun tertinggi di stasiun 2 sebanyak 132 tegakan $/ \mathrm{m}^{2}$ (rapat) sedangkan stasiun 1 sebanyak 95 tegakan $/ \mathrm{m}^{2}$ (agak rapat) dan stasiun 3 sebanyak 123 tegakan $/ \mathrm{m}^{2}$ (agak rapat). Lamun jenis Cymodocea serullata memiliki dominansi tertinggi pada setiap stasiun.
\end{abstract}

Kata Kunci: Nitrat; Fosfat; Air Pori Sedimen; Kolom Air; Lamun

\section{Nitrate And Phosphate Content in Pore Water and Water Columns Seagrass Fields of Prawean Coastal Waters, Jepara}

ABSTRACT: Naturally the concentration of nutrients in the waters varies for eachthe form of its compounds, including nitrates and phosphates. Seagrass plays an important role in the contribution of nutrients in waters with the result of decomposition of seagrass litter by decomposing microorganisms. The function of the seagrass system lies in understanding the factors that govern the production and decomposition of organic matter and the efficiency of nutrient cycling in the system. This research aims to determine the content of nitrate and phosphate in sediment pore water and water columns in the seagrass beds of Prawean Coast waters Jepara and determine the type and the amount of seagrass density. This research method uses descriptive analysis. Nitrate content analysis using SNI 06-6989.31-2005 and phosphate analysis using BP2-MU-A-08. Seagrass observations using the Transect squared $50 \times 50 \mathrm{~cm}$ according to the LIPI guidelines. The content of nitrates sediment pore water in the seagrass beds of Prawean Coast ranges from 1,85 to $2,82 \mathrm{mg} / \mathrm{l}$, while the content of nitrate in water column ranges from 0,63-1,09 mg/l. The content of phosphate in pore water ranges from 0,09-0,15 mg/l, while the phosphate content of the water column ranges from 0,02 to 0,04 mg/l. Four types of seagrass found were Enhalus accoroides, Thalassia hemprichii, Cymodocea serullata, and Cymodocea rotundata. The highest seagrass density at station 2 was $132 \mathrm{stands} / \mathrm{m}^{2}$, while the station 1 was 95 stands $/ \mathrm{m}^{2}$ and station 3 was 123 stands $/ \mathrm{m}^{2}$. Seagrass type Cymodocea Serullata has the highest dominance at each station.

Keywords: Nitrate; Phosphate; Sediment Pore Water; Water Column; Seagrass 


\section{PENDAHULUAN}

Produktivitas primer ekosistem lamun pada suatu perairan umumnya ditentukan oleh ketersediaan zat hara fosfat, nitrat dan ammonium yang berperan penting dalam menentukan fungsi lamun sebagai salah satu ekosistem laut dangkal yang penting (Susana dan Suyarso, 2008). Kandungan hara (fosfat, amonium dan nitrat nitrit) dalam air poros (air pori sedimen) di perairan padang lamun lebih tinggi daripada kadarnya dalam kolom air, hal ini disebabkan adanya aktivitas bakteri aerobik yang ada pada sekitar akar lamun yang dapat melarutkannya dalam bentuk kompleks dari unsur hara tersebut ke dalam sedimen Zulkifli (2003).

Dinamika nutrien memegang peranan penting pada ekosistem padang lamun dan ekosistem lainnya. Ketersediaan nutrien menjadi faktor pembatas pertumbuhan, kelimpahan dan morfologi lamun pada perairan (Nabilla et al., 2019). Kandungan nutrien di lingkungan perairan dan sedimen tergantung dari bentuk dan jumlah yang tepat, dan menentukan layak atau tidaknya kehidupan biota di laut. Seperti diketahui kandungan nutrien di ekosistem lamun dipengaruhi oleh kondisi lamunnya, hal ini karena fungsi lamun sebagai nutrient trap dan luruhan lamun yang mati (serasah lamun) menjadi sumber bahan organik di laut yang selanjutnya akan diubah oleh mikroorganisme menjadi nitrat.

Menurut Handayani et al., (2016), nitrat dan fosfat diserap oleh lamun melalui daun dan akar. Nutrien untuk pertumbuhan lamun didapatkan lebih banyak berasal dari air pori sedimen atau sediment pore water. Kandungan nutrien dalam kondisi tertentu dapat terjadi keadaan di luar batas yang dinyatakan aman untuk kategori perairan tertentu. Kondisi kerapatan lamun di padang lamun perairan pantai Prawean Bandengan, Jepara, dapat dikatakan masih relatif baik (Riniatsih dan Widianingsih, 2007).

Pantai Prawean terdapat hamparan lamun yang cukup luas yang menjadi salah satu ekosistem yang penting di perairan tersebut. Adanya aktivitas yang dilakukan oleh masyarakat di Desa Bandengan seperti aktivitas pertanian/persawahan, penangkapan biota, aktivitas lalu lalang keluar masuk kapal, dan aktivitas pengelolaan tambak diduga berpengaruh terhadap kandungan nitrat dan fosfat di perairan Pantai Prawean. Adanya aliran air dari parit tambak yang bermuara ke laut dapat menyebabkan tingginya unsur hara, sehingga dimungkinkan mengalami perubahan ekosistem lamun.

Penelitian ini bertujuan mengetahui kandungan nitrat dan fosfat pada air pori sedimen dan kolom air daerah padang lamun serta mengetahui jenis lamun dan jumlah kerapatan lamun yang terdapat di perairan Pantai Prawean Bandengan Jepara.Diharapkan penelitian ini dapat bermanfaat sebagai data referensi untuk penelitian selanjutanya.

\section{MATERI DAN METODE}

Penelitian dilakukan pada tanggal 13-27 Nopember 2019 di Perairan Pantai Prawean Bandengan, Jepara (Gambar 1) Materi yang digunakan pada penelitian ini adalah sampel air pori sedimen dan sampel kolom air untuk analisis nitrat dan fosfat serta lamun yang meliputi; identifikasi jenis dan kerapatan lamun. Penelitian ini mengambil data parameter fisika (suhu, kecerahan, kecepatan arus dan kedalaman) serta parameter kimia (salinitas pH dan DO) yang diambil secara langsung (in situ). Metode penelitian ini menggunakan analisis deskriptif bersifat kuantitatif dan eksploratif, yaitu metode penelitian yang bertujuan untuk menggali secara luas tentang sebab-sebab atau hal-hal yang mempengaruhi terjadinya sesuatu sehingga diperoleh hasil (Arikunto, 2011). Analisa kandungan nitrat menggunakan metode analisis SNI 06-6989.31-2005 dan fosfat menggunakan metode analisis BP2-MU-A-08. Pengamatan lamun menggunakan transek kuadrat $50 \times 50 \mathrm{~cm}$ menurut panduan LIPI.

Contoh uji air pori sedimen diambil pada tiap stasiun dengan metode coring (Li et al., 2019), menggunakan corer dari pipa paralon berukuran jari-jari $5 \mathrm{~cm}$ dan panjang $2 \mathrm{~m}$ kemudian corer ditancapkan pada kedalaman $20 \mathrm{~cm}$ untuk mendapatkan substrat sedimen, kemudian disimpan dalam pipa pralon dengan panjang $30 \mathrm{~cm}$ yang didalamnya sudah diberi plastik untuk mencegah kebocoran. Contoh uji kandungan nitrat dan fosfat diperlukan perlakuan khusus yaitu disimpan pada coolbox selama perjalanan menuju laboratorium agar sampel tidak rusak. Sampel yang akan dipres dikeluarkan terlebih dahulu dari pralon lalu dibungkus dengan kain parasut kemudian 
dimasukkan ke Pore Water Pressure. Dengan menggunakan dongkrak Pore Water Pressure ditekan keatas lalu menggunakan tekanan itu akan dihasilkan air pori sedimen melalui selang yang sudah dimodifikasi. Air pori sedimen ditampung sesuai kebutuhan kemudian dimasukkan kedalam botol sampel yang selanjutnya dibawa ke laboratorium untuk uji kandungan nitrat dan fosfat.

Metode purposive sampling digunakan untuk menentukan lokasi penelitian. Menurut Sugiyono (2009), teknik purposive sampling yaitu teknik penentuan lokasi dengan mempertimbangkan kondisi variabel penelitian yang akan diteliti. Tiga stasiun ini dipilih untuk mewakili tiga kondisi lingkungan yang berbeda. Stasiun 1 mewakili lingkungan perairan padang lamun dekat pemukiman warga, sawah dan outlet pengairan tambak., stasiun 2 mewakili lingkungan perairan padang lamun berdekatan dengan tempat penambatan perahu nelayan, kapal wisata untuk pantai Bandengan, pelabuhan kapal PT Pura Bahari dan tambak dan stasiun 3 mewakili lingkungan perairan padang lamun, pantai yang sering dikunjungi oleh masyarakat.

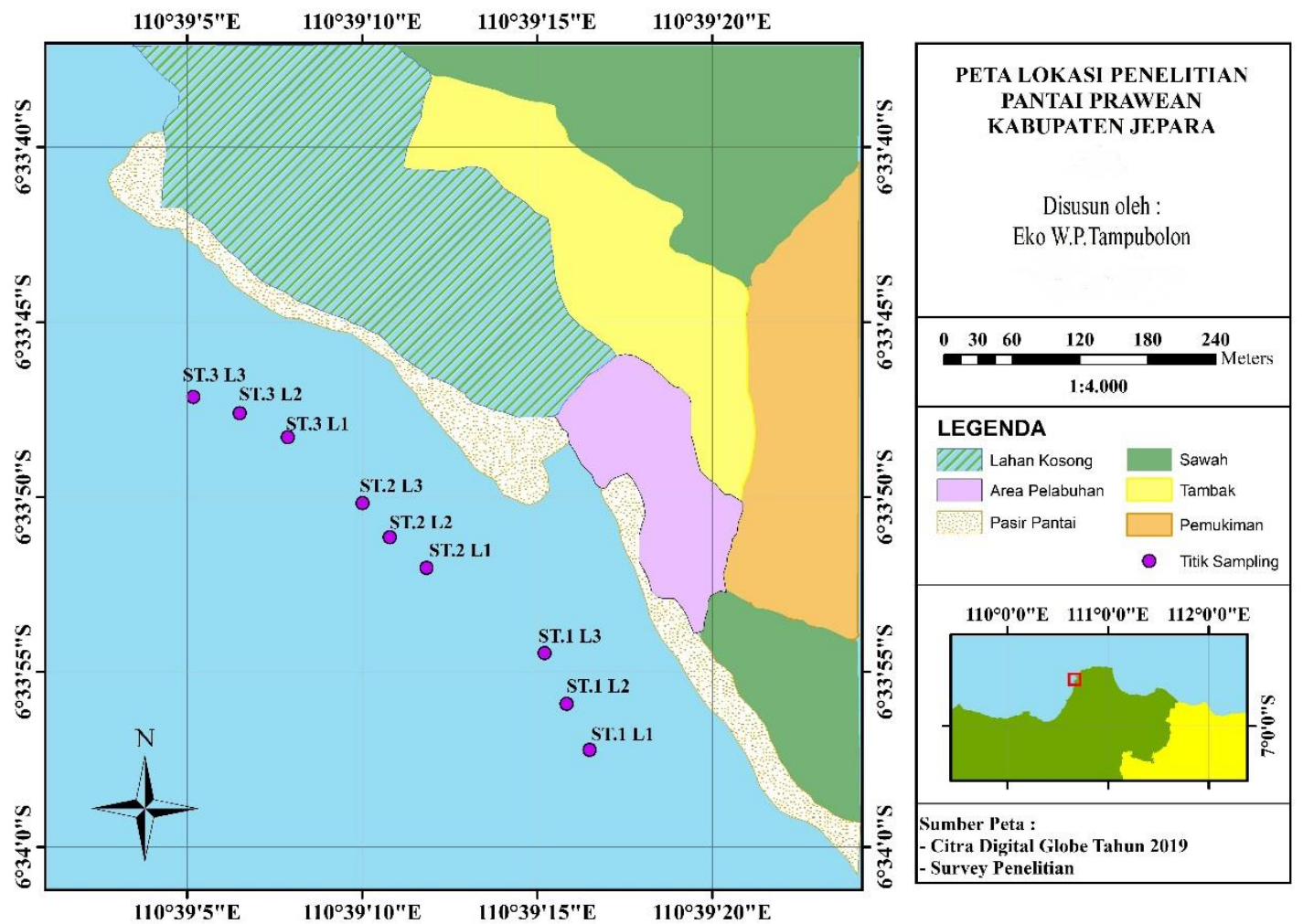

Gambar 1. Peta Lokasi Penelitan Pantai Prawean Jepara

Sampel air pori sedimen dianalisis kandungan nutriennya (nitrat dan fosfat) di Laboratorium Balai Pengujian dan Peralatan Dinas Pekerjaan Umum Bina Marga dan Cipta Karya Provinsi Jawa Tengah. Analisis kandungan nitrat menggunakan metode (IK-BP2-MU-A-08) dan kandungan fosfat mengunakan metode (SNI 06-6989.31-2005) dengan spektrofotometri. Contoh uji diukur secara duplo sebesar $25 \mathrm{~mL}$ dan masing-masing dimasukkan kedalam gelas $100 \mathrm{~mL}$. Asam klorida $1 \mathrm{~N}$ diitambahkan sebanyak $0,5 \mathrm{~mL}$ kemudian diaduk sampai rata. Absorbansi diukur pada panjang $220 \mathrm{~nm}$ dan $275 \mathrm{~nm}$. Perhitungan asorbansi nitrat dari contoh uji dihitung dengan cara mengurangkan absorbansi yang terbaca pada panjang gelombang $220 \mathrm{~nm}$ dengan absorbansi yang terbaca pada panjang gelombang $275 \mathrm{~nm}$.

Analisis kadar fosfat menggunakan contoh uji yang dipipet $50 \mathrm{~mL}$ secara duplo dan dimasukkan masing-masing ke dalam erlenmeyer, kemudian ditambahkan satu tetes indikator fenolftalin. $\mathrm{H}_{2} \mathrm{SO}_{4} 5 \mathrm{~N}$ ditambahkan jika terbentuk warna merah muda serta ditambahkan sampai warnanya hilang. Larutan campuran sebanyak $8 \mathrm{~mL}$ ditambahkan dan dihomogenkan, kemudian dimasukkan ke dalam kuvet pada alat spektrofotmeter. Hasil dianalisis pada panjang gelombang $880 \mathrm{~nm}$ dalam kisaran waktu 10 menit-30 menit. 
Kerapatan lamun jenis ke-i dihitung dengan persamaan menurut Rahmawati et al.(2014). Penetuan kerapatan lamun dilakukan pengambilan sampel yang didasarkan pada metode Transek Garis (English et al., 1994; Rahmawati et al., 2014). Kerapatan lamun dinyatakan sebagai jumlah individu/satuan luas dalam satuan meter persegi (Snedecor dan Cochran,1980).

\section{HASIL DAN PEMBAHASAN}

Kandungan nitrat dalam air pori sedimen di stasiun I berkisar antara 2,6414-2,9212 mg/l dengan rata - rata sebesar 2,8208 mg/l. Stasiun II berkisar antara 1,6203-2,3243 mg/l dengan rata - rata sebesar $2,0317 \mathrm{mg} / \mathrm{l}$ dan kandungan nitrat di stasiun III berkisar antara 1,7300-1,9452 $\mathrm{mg} / \mathrm{l}$ dengan rata - rata sebesar $1,8491 \mathrm{mg} / \mathrm{l}$. Kandungan nitrat pada kolom air di stasiun I berkisar antara $0,4768-1,1254 \mathrm{mg} / \mathrm{l}$ dengan kandungan rata - rata nya $0,8398 \mathrm{mg} / \mathrm{l}$. Stasiun II berkisar antara 0,5696-0,7134 mg/l dengan kandungan rata-rata nya sebesar 0,6337 $\mathrm{mg} / \mathrm{l}$ dan stasiun III berkisar antara 0,5735 - 1,4093 $\mathrm{mg} / \mathrm{l}$ dengan rata-rata sebesar 1,0853 mg/l. Kandungan nitrat dalam air pori sedimen di Stasiun I lebih tinggi daripada Stasiun II dan III dan kandungan nitrat dalam kolom air di Stasiun III lebih tinggi daripada Stasiun I dan II (Tabel 1).

Tabel 1. Kandungan nitrat $(\mathrm{mg} / \mathrm{l})$ air pori sedimen dan kolom air Padang Lamun di Perairan Pantai Prawean

\begin{tabular}{lllllll}
\hline \multirow{2}{*}{ Tanggal } & \multicolumn{3}{c}{ Nitrat Air Pori Sedimen $(\mathrm{mg} / \mathrm{l})$} & \multicolumn{3}{c}{ Nitrat Kolom Air $(\mathrm{mg} / \mathrm{l})$} \\
\cline { 2 - 7 } & \multicolumn{1}{c}{ Stasiun I } & \multicolumn{1}{c}{ Stasiun II } & Stasiun III & \multicolumn{1}{c}{ Stasiun I } & \multicolumn{1}{c}{ Stasiun II } & Stasiun III \\
\hline $13 / 11 / 2019$ & 2,6414 & 1,6203 & 1,7300 & 0,4768 & 0,5696 & 1,4093 \\
$20 / 11 / 2019$ & 2,9212 & 2,3243 & 1,9452 & 1,1254 & 0,7134 & 0,5735 \\
$27 / 11 / 2019$ & 2,8998 & 2,1504 & 1,8722 & 0,9171 & 0,6181 & 1,2731 \\
Rata - rata & 2,8208 & 2,0317 & 1,8491 & 0,8398 & 0,6337 & 1,0853 \\
STDEV & 0,16 & 0,37 & 0,11 & 0,33 & 0,07 & 0,45 \\
\hline
\end{tabular}

Kandungan nitrat pada air pori sedimen yang dijumpai pada Stasiun I dengan nilai berkisar $2.641-2.921 \mathrm{mg} / \mathrm{l}$ dengan rata rata $2,820 \mathrm{mg} / \mathrm{l}$, tergolong kategori sedang/optimum. Secara umum kandungan nitrat ini masih tinggi di atas kandungan nitrat yang umum dijumpai di perairan laut. Kadar nitrat yang normal di perairan laut umumnya berkisar antara 0,001-0,007 mg/l (Patty et al., 2015). Hal tersebut disebabkan karena pada stasiun tersebut adalah stasiun yang dekat dengan outlet pengairan dari tambak serta sawah sehingga menerima masukan (run-off) dari lahan pertanian/persawahan yang pada umumnya banyak mengandung nitrat. Skala kondisi lamun (agak rapat 75-125 tegakan $/ \mathrm{m}^{2}$ ) berdasarkan kerapatan (Braun-Blanquet, 1965), kerapatan lamun stasiun I tergolong kategori agak rapat yaitu 94 tegakan $/ \mathrm{m}^{2}$.

Padang lamun memiliki fungsi ekologi utama dalam daur zat hara di lingkungan laut. Sehingga dapat dipastikan, lamun ini menyumbang ke dalam ekosistem pantai melalui detritus, yakni serpih-serpih bahan organik (daun, rimpang) yang membusuk dan menjadi bahan makanan berbagai organisme pemakan detritus. Hal ini didukung dengan keberadaan DO di stasiun tersebut yang berada pada kisaran yang normal yaitu $8 \mathrm{mg} / \mathrm{l}$. Sumber DO yang mencukupi di lokasi pengamatan dan merupakan kondisi perairan yang kondusif untuk terbentuknya nitrat sebagai nutrien $\mathrm{N}$ yang diperlukan oleh produser di air laut. Peranan nitrat yang terkandung di dalam air pori sedimen dan kolom air di daerah padang lamun adalah sebagai unsur penting bagi pertumbuhan dan kelangsungan hidup organisme didalamnya. Hal tersebut sesuai pernyataan Jones \& Lee (2005), bahwa nitrat merupakan parameter yang sangat berpengaruh terhadap kehidupan biota laut. Kandungan nitrat cukup tinggi dalam air pori sedimen disebabkan kecepatan penggunaan oleh bakteri denitrifikasi dan bakteri anaerob. Nitrat $\left(\mathrm{NO}_{3}{ }^{-}\right)$sebagai derivat nitrogen, berasal dari proses oksidasi yang panjang. Untuk nitrat berasal dari oksidasi $\mathrm{N}$-ammonia $\left(\mathrm{NH}_{3}\right)$. Senyawa $\mathrm{NH}_{3}$ ini merupakan senyawa yang paling banyak ditemukan di air buangan. Untuk membentuk nitrat $\left(\mathrm{NO}_{3}{ }^{-}\right)$, senyawa $\mathrm{NH}_{3}$ ini dioksidasi secara biologis jika ada oksigen. Proses 
oksidasi untuk pembentukan nitrat ini dibantu oleh bakteri nitrifikasi yaitu Nitrosomonas dan Nitrobacter (Hastuti, 2011).

Mason (1981), menyatakan bahwa berdasarkan kecepatan arus perairan dikelompokkan berarus sangat cepat dengan kisaran $>1 \mathrm{~m} / \mathrm{s}$, berarus cepat dengan kisaran 0,5-1 m/s, berarus sedang dengan kisaran $0,25-0,5 \mathrm{~m} / \mathrm{s}$, berarus lambat dengan kisaran $0,1-0,25 \mathrm{~m} / \mathrm{s}$ dan berarus sangat lambat dengan kisaran $<0,1 \mathrm{~m} / \mathrm{s}$. Kecepatan arus pada lokasi penelitianl termasuk kategori berarus sedang. Arus yang lemah mengakibatkan pengadukan di substrat sedimen cenderung kecil yang megakibatkan kandungan nitrat dalam sedimen juga semakin tinggi dan juga sebaliknya.

\section{Kandungan Fosfat pada Air Pori Sedimen dan Kolom Air}

Kandungan fosfat dalam air pori sedimen di perairan padang lamun dekat pemukiman warga, sawah dan outlet pengairan tambak (Stasiun I) berkisar 0,1076-0,1825 mg/l dengan rata - rata sebesar 0,1502 mg/l. Kandungan fosfat dalam air pori sedimen di perairan padang lamun berdekatan dengan tempat penambatan perahu nelayan, kapal wisata untuk pantai Bandengan, pelabuhan kapal PT Pura Bahari dan tambak (Stasiun II) berkisar antara 0,0755 - 0,1091 mg/l dengan rata-rata sebesar $0,0924 \mathrm{mg} / \mathrm{l}$ dan pada perairan padang lamun, pantai yang sering dikunjungi oleh masyarakat (Stasiun III) berkisar antara 0,0581-0,1252 $\mathrm{mg} / \mathrm{l}$ dengan rat-rata sebesar 0,0892 mg/l (Tabel 2).

Tabel 2. Kandungan fosfat $(\mathrm{mg} / \mathrm{l})$ air pori sedimen dan kolom air Padang Lamun di perairan Pantai Prawean

\begin{tabular}{lllllll}
\hline \multirow{2}{*}{ Tanggal } & \multicolumn{3}{c}{ Fosfat Pore Water $(\mathrm{mg} / \mathrm{l})$} & \multicolumn{3}{c}{ Fosfat Kolom Air $(\mathrm{mg} / \mathrm{l})$} \\
\cline { 2 - 7 } & \multicolumn{1}{c}{ Stasiun I } & \multicolumn{1}{c}{ Stasiun II } & Stasiun III & \multicolumn{1}{c}{ Stasiun I } & Stasiun II & Stasiun III \\
\hline $13 / 11 / 2019$ & 0,1076 & 0,0755 & 0,0581 & 0,0348 & 0,0225 & 0,0018 \\
$20 / 11 / 2019$ & 0,1825 & 0,1091 & 0,0844 & 0,0822 & 0,0236 & 0,0658 \\
$27 / 11 / 2019$ & 0,1604 & 0,0925 & 0,1252 & 0,0129 & 0,0148 & 0,0227 \\
Rata - rata & 0,1502 & 0,0924 & 0,0892 & 0,0433 & 0,0203 & 0,0301 \\
STDEV & 0,04 & 0,02 & 0,03 & 0,04 & 0,00 & 0,03 \\
\hline
\end{tabular}

Kandungan fosfat dalam kolom air pada stasiun I berkisar antara 0,0129-0,0822 mg/l dengan kandungan rata-rata nya sebesar $0,0433 \mathrm{mg} / \mathrm{l}$. Stasiun II berkisar antara 0,0148-0,0236 $\mathrm{mg} / \mathrm{l}$ dengan rata - rata sebesar $0,0203 \mathrm{mg} / \mathrm{l}$ dan pada stasiun III berkisar antara 0,0018-,0658 $\mathrm{mg} / \mathrm{l}$ dengan kandungan rata-rata nya sebesar $0,0301 \mathrm{mg} / \mathrm{l}$. Kandungan fosfat dalam air pori sedimen dan kolom air di dekat pemukiman warga, sawah dan outlet pengairan tambak (Stasiun I) lebih tinggi daripada Stasiun II dan III, hal ini disebabkan karena letak Stasiun I yang berada di sekitar outlet pengairan tambak, diduga disebabkan karena daratan yang terkikis menjadi mineralmineral terlarut dan mengalir ke perairan terbuka. Disamping itu, di sekitar outlet pengairan tambak juga padat dengan pemukiman penduduk sehingga limbah-limbah rumah tangga masuk ke dalam perairan dan memperkaya ketersediaan fosfat di perairan tersebut.

Penelitian yang dilakukan pada bulan Nopember 2019, didapatkan kandungan fosfat air pori sedimen pada stasiun I berkisar 0.107-0.182 $\mathrm{mg} / \mathrm{l}$ dengan rata rata 0,150 $\mathrm{mg} / \mathrm{l}$, tergolong sangat subur. Berdasarkan Keputusan Menteri Lingkungan Hidup Nomor 51 Tahun 2004 tentang Baku Mutu Air Laut, nilai ambang batas kadar fosfat untuk biota laut adalah 0,015 mg/l. Kadar fosfat yang tinggi dipengaruhi musim barat (Oktober, Nopember, Desember, Januari, Februari) yang bertepatan dengan musim hujan sangat berpotensi untuk meningkatkan kadar fosfat yang berasal dari daratan. Pada stasiun I kandungan nitrat dan fosfat di kolom air lebih tinggi dibanding stasiun II, hal ini karena kandungan nutrien (nitrat dan fosfat) di stasiun I disebabkan karena adanya intensitas suplai bahan organik yang masuk ke perairan melalui aliran sungai kecil dari pertambakan warga yang banyak mengandung zat hara $\mathrm{N}$ dan $\mathrm{P}$. 
Secara keseluruhan nilai rata - rata kandungan fosfat dalam air pori sedimen dan kolom air padang lamun di perairan Pantai Prawean, masing - masing sebesar 0,1106 mg/l dan 0,0312 mg/l, sesuai dengan kadar fosfat yang dijumpai di perairan laut yang normal. Kadar fosfat di perairan laut yang normal berkisar antara 0,00031-0,124 mg/l (Edward \& Tarigan, 2003). Perairan Pantai Prawean memiliki karakteristik dengan perairannya yang tenang, kecepatan arus rendah, topografi pantai cekung, bersubstrat (lumpuran, pasir lumpuran, pasir karang, dan puing karang). Perairan yang tenang membuat kandungan fosfat di badan air terdeposisi ke dalam pori sedimen melalui proses sedimentasi, adsorbsi dan presipitasi. Kondisi ini sesuai dengan pendapat Muchtar dan Simanjuntak (2008), bahwa secara alamiah fosfat terdistribusi mulai dari permukaan sampai dasar. Semakin ke dasar semakin tinggi konsentrasinya sebagai akibat dari dasar laut yang kaya nutrisi dan konsentrasinya semakin rendah semakin jauh ke arah laut.

\section{Kerapatan Jenis dan Kerapatan Relatif Lamun}

Berdasarkan Tabel 3 dan Gambar 5, diketahui bahwa jenis lamun yang memiliki jumlah tegakan tertinggi yaitu Cymodocea serrulata dengan nilai kerapatan jenis yaitu 170,55 tegakan $/ \mathrm{m}^{2}$, selanjutnya diikuti oleh lamun jenis Cymodocea rotundatta dengan nilai kerapatan jenis yaitu 84,97 tegakan $/ \mathrm{m}^{2}$, kemudian diikuti oleh jenis Thalassia hemprichii dengan nilai kerapatan jenis yaitu 49,21 tegakan $/ \mathrm{m}^{2}$, dan lamun dengan jumlah nilai kerapatan jenis terendah adalah jenis Enhalus acoroides dengan jumlah kerapatan jenis yaitu 44,97 tegakan $/ \mathrm{m}^{2}$.

Tabel 3. Kerapatan Jenis dan Kerapatan Relatif Lamun

\begin{tabular}{lcccccc}
\hline \multirow{2}{*}{ Jenis Lamun } & \multicolumn{3}{c}{ Kerapatan $\left(\right.$ Tegakan $\left./ \mathrm{m}^{2}\right)$} & & $\mathrm{Kj}$ & $\mathrm{Kr}$ \\
\cline { 2 - 4 } & Stasiun I & Stasiun II & Stasiun III & & $\left(\right.$ Tegakan $\left./ \mathrm{m}^{2}\right)$ & $(\%)$ \\
\hline T. hemprichii & 11 & 25 & 13 & & 49 & 14,07 \\
C. serrulata & 51 & 53 & 66 & & 171 & 48,77 \\
C. rotundata & 23 & 34 & 28 & 85 & 24,30 \\
E. acoroides & 9 & 20 & 16 & 45 & 12,86 \\
Total & 94 & 132 & 123 & & 350 & 100 \\
\hline
\end{tabular}

Lamun yang ditemukan di perairan pantai Prawean desa Bandengan Jepara merupakan vegetasi lamun campuran karena terdiri dari 4 spesies lamun, yaitu Enhalus accoroides, Thalassia hemprichii, Cymodocea serullata, dan Cymodocea rotundata. Menurut Asriyana dan Yuliana (2012), vegetasi campuran adalah vegetasi yang terdiri dari 2 sampai 12 jenis lamun yang tumbuh bersama-sama dalam satu substrat. Perairan Pantai Prawean Jepara banyak ditemukan lamun jenis Cymodocea serullata. Pernyataan tersebut sesuai dengan kondisi substrat yang ditemukan pada perairan Pantai Prawean, Cymodocea serrulata dapat berkembang baik dengan substrat pasir, pecahan karang dan sedikit berlumpur. Sedangkan jenis lamun yang sedikit jumlahnya adalah Enhalus acoroides. Karakteristik substrat pasir atau pasir berlumpur merupakan jenis substrat yang sesuai untuk pertumbuhan lamun jenis Cymodocea serrulata dan Cymodocea rotundata (Terrados et al., 1999). Riniatsih (2016), menjelaskan bahwa jenis lamun Cymodocea serrulata dan Cymodocea rotundata merupakan jenis lamun yang banyak ditemukan di habitat bersubstrat pasir halus yang kaya dengan kandungan bahan organik.

Berdasarkan hasil perhitungan kerapatan relatif, lamun yang memiliki nilai kerapatan relatif tertinggi yaitu jenis Cymodocea serrulata, dengan nilai persentase kerapatan $48,77 \%$ dari seluruh jenis lamun yang ditemukan di perairan pantai Prawean. Sedangkan kerapatan relatif terendah yaitu jenis Enhalus acoroides dengan persentase nilai yaitu 12,86 \% dari seluruh jenis lamun yang ditemukan (Gambar 2).

Hasil perhitungan kerapatan lamun setiap stasiun dari pengukuran yang dilakukan di lokasi penelitian maka didapatkan hasil yaitu kerapatan lamun pada Stasiun I sebesar $94 \mathrm{Tegakan} / \mathrm{m}^{2}$, Stasiun II 132 Tegakan $/ \mathrm{m}^{2}$ dan Stasiun III sebesar 123 Tegakan $/ \mathrm{m}^{2}$. Jumlah kerapatan lamun yang ditemukan di setiap stasiun penelitian disajikan dalam bentuk grafik berikut (Gambar 3).

Berdasarkan hasil pengamatan lamun, stasiun I dengan nilai kerapatan 94 tegakan $/ \mathrm{m}^{2}$ termasuk dalam kategori agak rapat. Hal ini dimungkinkan karena karakteristik substrat yang 
berbeda antar stasiun, sebaran pertumbuhan lamun yang tidak tersebar secara merata dan beberapa faktor lingkungan lainnya seperti kondisi lingkungan yang berbeda. Hasil perhitungan kerapatan lamun, diperoleh data yaitu lamun pada stasiun II memiliki kerapatan yang paling tinggi dibandingkan dengan stasiun I dan stasiun III yaitu dengan nilai kerapatan 132 tegakan $/ \mathrm{m}^{2}$ termasuk dalam kategori rapat. Tingginya kerapatan lamun lamun pada stasiun II dipengaruhi oleh substrat dan nutrien pada stasiun ini. Tomascick et al. (1997), menyebutkan bahwa keberadaan lamun disuatu perairan tergantung pada kondisi perairan atau habitat lamun dapat tumbuh. Perbedaan karakteristik substrat mempengaruhi pertumbuhan lamun. Sedimen merupakan tempat sumber utama mendapatkan nutrien, karena sedimen mengandung kadar nutrien (hara makro maupun mikro) yang lebih tinggi, sedangkan kolom air mempunyai kadar nutrien yang rendah (Silvia et al., 2014). Di daerah tropis, konsentrasi nutrien yang larut dalam perairan lebih rendah dibandingkan konsentrasi nutrien di sedimen (Silvia et al., 2014).

Ekosistem lamun merupakan salah satu ekosistem yang produktif. Di samping itu, ekosistem lamun mempunyai peranan penting dalam menunjang keberadaan nitrat dan fosfat di perairan. Lamun memegang peranan penting dalam pendauran berbagai zat hara dan elemen- elemen yang langka di lingkungan laut. Detritus daun lamun yang tua didekomposisi oleh sekumpulan jasad bentik, sehingga dihasilkan bahan organik yang tersuspensi maupun terlarut dalam bentuk nutrien. Keberadaan nitrat dan fosfat di perairan sangat penting bagi ekosistem lamun, karena nitrat dan fosfat merupakan nutrien terpenting dalam pertumbuhan ekosistem lamun tersebut, sebaliknya kontribusi nitrat dan fosfat di dalam ekosistem lamun berasal dari ekosistem itu sendiri oleh serasah yang dihasilkan dari daun lamun yang jatuh dan membusuk (Sitorus et al., 2016).

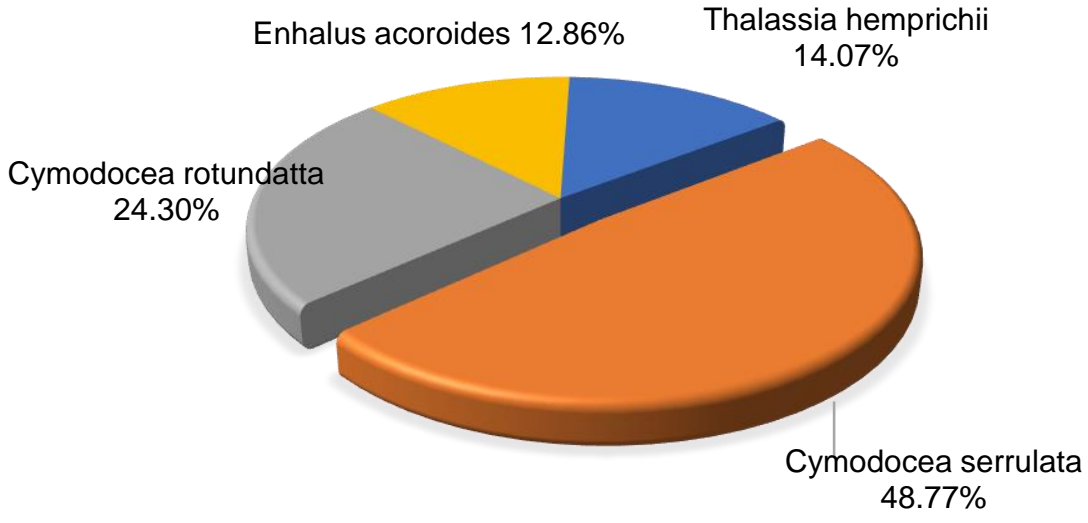

Gambar 2. Kerapatan Relatif Lamun

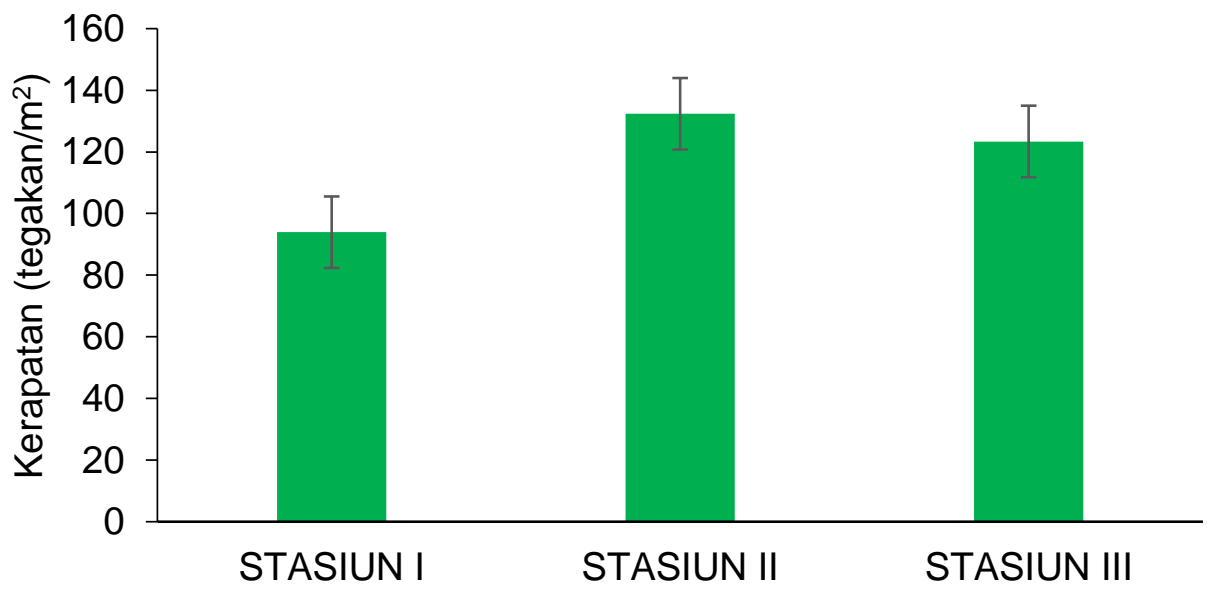

Gambar 3. Kerapatan Lamun 
Berdasarkan hasil penelitian yang dilakukan di perairan Pantai Prawean, lamun memberikan kontribusi yang cukup bagi keberadaan nutrien (nitrat dan fosfat). Pada air pori sedimen di stasiun I dengan kerapatan lamun 94 tegakan $/ \mathrm{m}^{2}$ memiliki kandungan nitrat sebesar 2,82 $\mathrm{mg} / \mathrm{l}$ dan fosfat sebesar 0,15 mg/l. Stasiun II dengan kerapatan lamun 132 tegakan/ $\mathrm{m}^{2}$ memiliki kandungan nitrat sebesar 2,03 $\mathrm{mg} / \mathrm{l}$ dan fosfat sebesar $0,09 \mathrm{mg} / \mathrm{l}$ serta untuk stasiun III dengan kerapatan lamun 123 tegakan $/ \mathrm{m}^{2}$ memiliki kandungan nitrat sebesar $1,85 \mathrm{mg} / \mathrm{l}$ dan fosfat sebesar $0,09 \mathrm{mg} / \mathrm{l}$ (Gambar 4). Jika dilihat berdasarkan kerapatan/ kepadatan lamun, stasiun I memiliki kerapatan lamun yang lebih rendah daripada stasiun II dan III, sementara untuk kandungan nitrat dan fosfat justru lebih tinggi pada stasiun I. Oleh karena itu keberadaan nitrat dan fosfat dalam air pori sedimen di perairan, tidak hanya bersumber dari lamun itu sendiri melalui proses penguraian pelapukan ataupun dekomposisi, tetapi juga berasal dari daratan melalui aliran sungai yang terdiri dari berbagai limbah rumah tangga dan limbah dari pertambakan warga yang mengandung senyawa organik.

Stasiun I memiliki jumlah kerapatan lamun 94 tegakan $/ \mathrm{m}^{2}$ dengan kandungan nutrien di kolom air yaitu nitrat sebesar $0,84 \mathrm{mg} / \mathrm{l}$ dan fosfat sebesar $0,04 \mathrm{mg} / \mathrm{l}$. Sedangkan pada stasiun II dengan jumlah kerapatan lamun tertinggi yaitu 132 tegakan $/ \mathrm{m}^{2}$ memiliki kandungan nutrien di kolom air terendah yaitu nitrat sebesar $0,63 \mathrm{mg} / \mathrm{l}$ dan fosfat sebesar $0,02 \mathrm{mg} / \mathrm{l}$. Sementara pada stasiun III dengan kerapatan lamun 123 tegakan $/ \mathrm{m}^{2}$ memiliki kandungan nitrat di kolom air yang tinggi dari semua stasiun yaitu sebesar $1,09 \mathrm{mg} / \mathrm{l}$ dan kandungan fosfat sebesar $0,03 \mathrm{mg} / \mathrm{l}$ (Gambar 5). Rendahnya kandungan nitrat dan fosfat kolom air pada stasiun II diduga karena kurang mendapat masukan (run-off) dari lahan pertanian dan sawah yang pada umumnya banyak mengandung zat hara (nitrat dan fosfat). Menurut European Commision (2002), sumber utama pengkayaan $\mathrm{N}$ dan $\mathrm{P}$ adalah run-off yang berasal dari lahan pertanian/sawah.

\section{Parameter Kualitas Perairan Pantai Prawean}

Hasil pengukuran parameter kimia fisika pada tiap stasiun penelitian yang diambil secara langsung di lapangan yaitu suhu, salinitas, kecerahan, $\mathrm{pH}, \mathrm{DO}$, kecepatan arus dan kedalaman. Berdasarkan parameter pendukung di perairan pantai Prawean Jepara didapatkan data Salinitas berkisar antara 32-33,2 ppt, Parameter Oksigen terlarut dalam air (DO) rata- rata 7,2-8 mg/L, $\mathrm{pH}$ didapatkan hasil rata- rata 7,5-8, suhu perairan saat pengambilan data di pantai Prawean berkisar $29,5-30,2^{\circ} \mathrm{C}$, pada saat pengambilan data kecerahan perairan dapat dilihat sampai dasar perairan. Kedalaman pada saat pengambilan data kerapatan lamun berkisar antara 0,40-0,65 m. Kecepatan arus berkisar 0,22-0,31 m/s (Tabel 4).

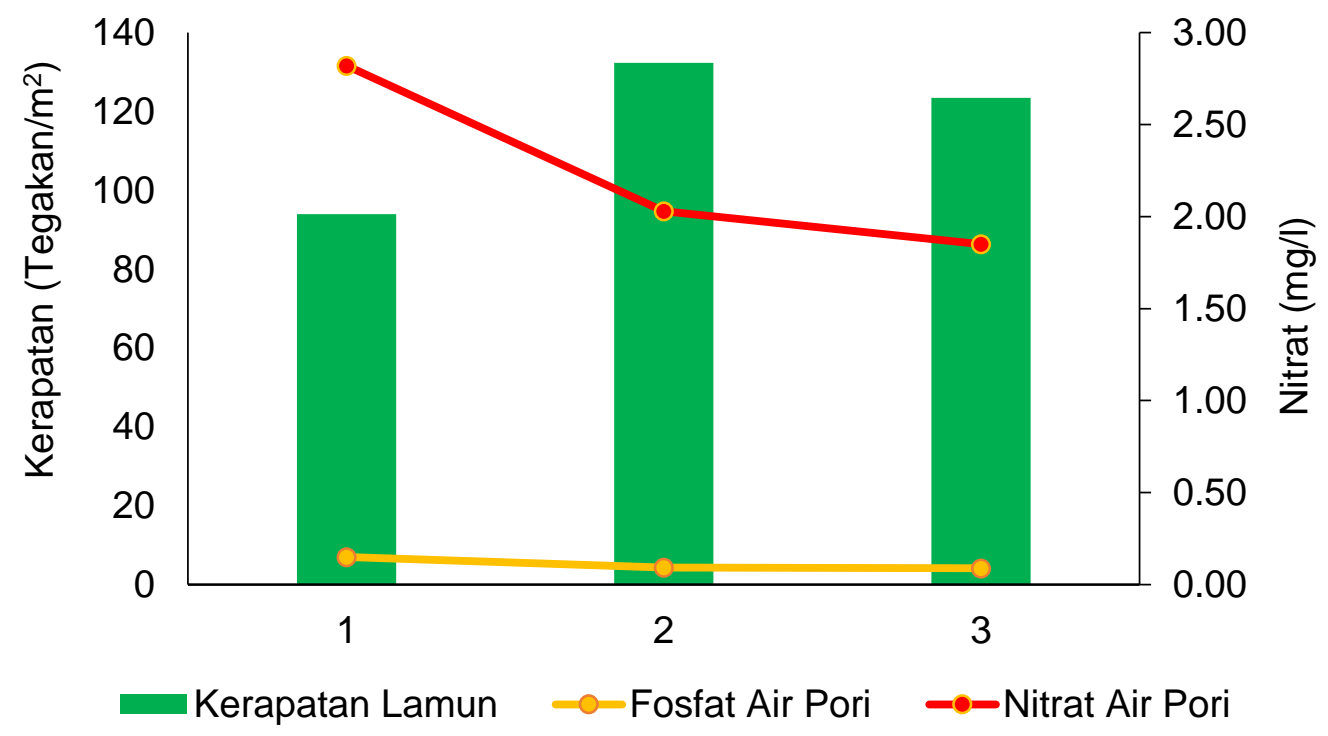

Gambar 4. Kerapatan Lamun dan Kandungan Nitrat Fosfat Air Pori 


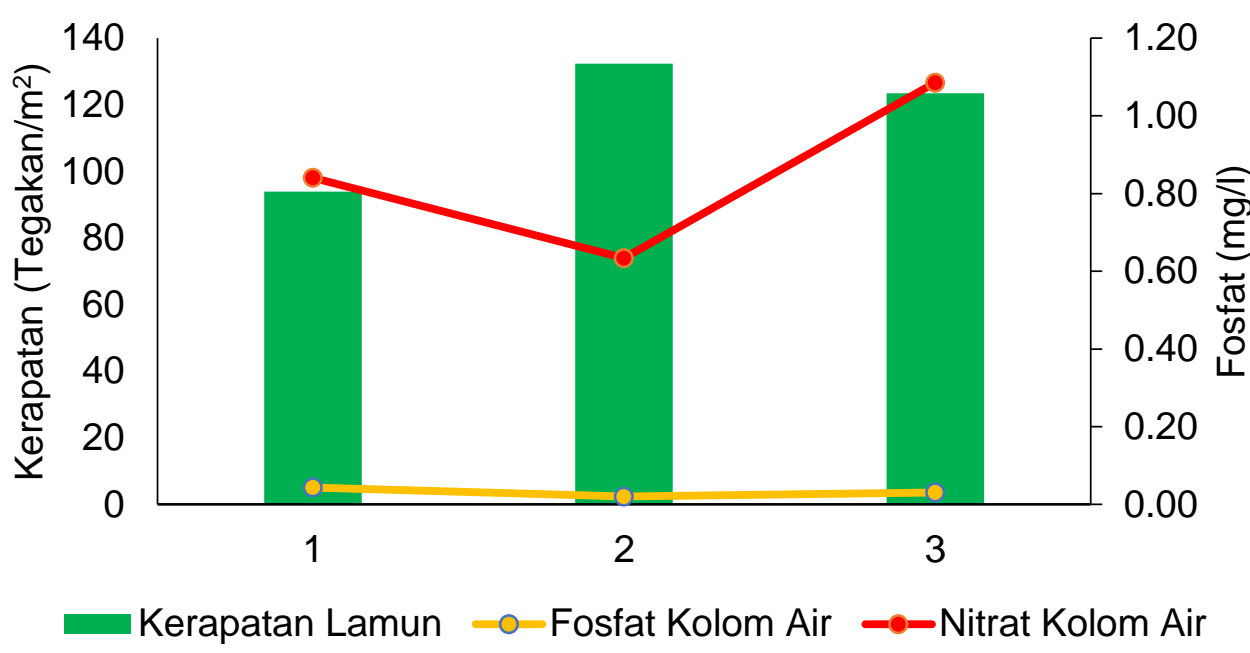

Gambar 5. Kerapatan Lamun dan Kandungan Nitrat Fosfat Kolom Air

Tabel 4. Parameter lingkungan di Perairan Prawean, Jepara

\begin{tabular}{|c|c|c|c|c|}
\hline \multirow[b]{2}{*}{ Parameter Perairan } & \multicolumn{3}{|c|}{ Stasiun } & \multirow{2}{*}{$\begin{array}{c}\text { Baku Mutu } \\
\text { Ekosistem Lamun*) }\end{array}$} \\
\hline & 1 & II & III & \\
\hline Suhu $\left({ }^{\circ} \mathrm{C}\right)$ & 30.2 & 29.5 & 29.6 & $28-30$ \\
\hline Salinitas (ppt) & 32.3 & 32 & 33.2 & $33-34$ \\
\hline Kecerahan (m) & $75 \%$ & $70 \%$ & $80 \%$ & $>3$ \\
\hline $\mathrm{pH}$ & 7.5 & 8 & 8 & $7-8.5$ \\
\hline $\mathrm{DO}(\mathrm{mg} / \mathrm{l})$ & 8 & 7.8 & 7.2 & $>5$ \\
\hline Kecepatan Arus (m/s) & 0.22 & 0.31 & 0.25 & - \\
\hline Kedalaman $(\mathrm{m})$ & 0.65 & 0.40 & 0.45 & - \\
\hline
\end{tabular}

Sumber baku mutu*: Keputusan Menteri Negara Lingkungan Hidup No. 51 Tahun 2004

Kecerahan perairan yang teramati pada perairan Pantai Prawean (Tabel 4) adalah $70-80 \%$ yang berarti bahwa pada lokasi pengamatan penyinaran masih terjadi sampai kedalaman tertentu. Berdasarkan data tersebut dapat di ketahui bahwa perairan Pantai Prawean termasuk perairan dangkal dan jernih karena sampai kedalaman tertentu cahaya dapat masuk. Kondisi perairan yang dangkal mempengaruhi kehidupan lamun, karena perubahan kedalaman air dapat mempengaruhi beberapa faktor lingkungan perairan yang lain, yaitu suhu, intensitas cahaya dan hidrodinamika air. Intensitas cahaya matahari yang sampai kedalaman tertentu diperairan merupakan faktor pembatas pertumbuhan dan produksi lamun (Syawal et al., 2019).

Kondisi perairan pantai Prawean menunjukkan bahwa kecepatan arus perairan termasuk berarus sedang dengan kisaran 0,22-0,31 m/s. Populasi vegetasi lamun di daerah ini cukup rapat sehingga mampu memperlambat gerakan arus air yang disebabkan oleh ombak laut. Faktor fisika dan kimia sangat berpengaruh terhadap kelangsungan hidup organisme perairan. Kisaran nilai salinitas di Pantai Prawean berkisar antara $32-33,2$ ppt. Salinitas terendah terdapat di stasiun II. Nilai optimum salinitas untuk lamun adalah 33-34 ppt (KepMenLH No.51/MENLH, 2004). Nilai derajat keasaman $(\mathrm{pH})$ di lokasi pengamatan berturut-turut sekitar 7,5 - 8. Hal ini dimungkinkan pengaruh dari faktor cuaca dimana pada saat pengamatan kondisi cuaca cerah dan tidak hujan yang mengakibatkan $\mathrm{pH}$ perairan tetap normal.

\section{KESIMPULAN}

Kandungan zat hara (fosfat dan nitrat) dalam air pori sedimen di perairan padang lamun Prawean Jepara didapatkan lebih tinggi daripada kadarnya dalam kolom air, hal ini disebabkan 
adanya aktivitas bakteri aerobik yang ada pada sekitar akar lamun yang dapat melarutkannya dalam bentuk kompleks dari unsur hara tersebut ke dalam sedimen, serta produktivitas serasah lamun yang terdekomposisi.

\section{DAFTAR PUSTAKA}

Arikunto, S. 2011. Prosedur Penelitian: Suatu Pendekatan Praktik. Rineka Cipta. Jakarta. 413 hlm. Asriyana \& Yuliana. 2012. Produktivitas Perairan. Bumi Aksara. Jakarta.

Edward \& Tarigan, M.S. 2003. Pengaruh Musim Terhadap Fluktuasi Kandungan Fosfat Dan Nitrat Di Laut Banda. Makara Sains Jakarta,7(2): 82-89.

European Commission, 2002. Implementation of Council Directive 91/676/EEC concerning the protection of waters against pollution caused by nitrates from agricultural sources: Synthesis from year 2000 Member States reports Luxembourg: Office for Official Publications of the European Communities, 2002. ISBN 92-894-4103-8

Handayani, R.D., Armid \& Emiyarti. 2016. Hubungan Kandungan Nutrien Dalam Substrat Terhadap Kepadatan Lamun Di Perairan Desa Lalowaru Kecamatan Moramo Utara. Jurnal IImu Kelautan, 1(2):42-53.

Hastuti, Y.P. 2011. Nitrifikasi dan Denitrifikasi Di Tambak. Jurnal Akuakultur Indonesia., 10(1):8998.

Jones-Lee, A. \& Lee, G.F. 2005. Eutrofication (Excessive Fertilization) Water Enyclopedia: Surface and Agricultural water. Wiley, Hoboken, NJ. 107-114 p.

Keputusan Menteri Lingkungan Hidup Nomor 51 Tahun 2004. Kriteria Baku Mutu Air Laut Untuk Kehidupan Biota Laut. Sekretariat Negara. Jakarta.

Mason, C.F. 1981. Biology of Freshwater Pollution. London and New York: Longman, 250 p.

Muchtar, M. \& Simanjuntak, M. 2008. Karakteristik dan Fluktuasi Zat Hara Fosfat, Nitrat dan Derajat Keasaman $(\mathrm{pH})$ di Estuary Cisadane pada Musim yang Berbeda. LIPI Press, Jakarta, pp. 139-148.

Nabilla, S., Hartati, R. \& Nuraini, R.A.T. 2019. Hubungan Nutrien pada Sedimen dan Penutupan Lamun Di Perairan Jepara. Jurnal Kelautan Tropis, 22(1):42-48.

Patty, S.I., Arfah H. \& Abdul, M.S. 2015. Zat Hara (Fosfat, Nitrat), Oksigen Terlarut dan pH Kaitannya dengan Kesuburan di Perairan Jikumerasa, Pulau Buru. Jurnal Pesisir dan Laut Tropis, 3(1):43-50.

Rahmawati, S., Irawan, A., Supriyadi, I.H. \& Azkab, M.H. 2014. Panduan Monitoring Padang Lamun. CRITC COREMAP CTI LIPI, Jakarta, $37 \mathrm{hlm}$.

Riniatsih, I. \& Widianingsih. 2007. Kelimpahan dan Pola sebaran Kerang-kerangan (Bivalve) di Ekosistem Padang Lamun Perairan Jepara. Jurnal IImu Kelautan, 12(1):53-58.

Riniatsih, I. 2016. Distribusi Jenis Lamun Dihubungkan dengan Sebaran Nutrien Perairan di Padang Lamun Teluk Awur Jepara. Jurnal Kelautan Tropis, 19(2):101-107.

Sitorus, T., Zulkifli \& Efriyeldi. 2016. Nitrates and Phosphates Content in the Water and Sediment in Seagrass Ecosystem in the North of Coastal Area of Rupat Sub Distric Bengkalis Riau. Jurnal Online Mahasiswa Fakultas Perikanan dan Ilmu Kelautan Universitas Riau. $11 \mathrm{hlm}$.

Sugiyono. 2009. Metode Penelitian Kuantitatif, Kualitatif dan R\&D. Alfabeta, Bandung, 440 hlm.

Susana, T. \& Suyarso. 2008. Penyebaran Fosfat dan Deterjen di Perairan Pesisir dan Luat Cirebon Jawa Barat. Pusat Penelitian Oseanografi., 34:117-131.

Syawal, A.M., Ira \& Afu, L.O.A. 2019. Laju Pertumbuhan Dan Kelangsungan Hidup Lamun Hasil Transplantasi Di Perairan Teluk Kendari. Jurnal Sapa Laut, 4(2):69-77.

Terrados, J., Agawin, N.S., Duarte, C.M., Fortes, M.D., Kamp-Nielsen, L. \& Borum, J. 1999. Nutrient Limitation of the Tropical Seagrass Enhalus acoroides (L.) Royle in Cape Bolinao, NW Philippines. Aquatic Botany, 65(1):123-139.

Tomascick, T., Mah, A.J., Nontji, A. \& Moosa M.K.K. 1997. The Ecology of the Indonesia Seas. Part One. Periplus Edition (HK) Ltd. Singapore.

Zulkifli, E. 2003. Kandungan Zat Hara Dalam Air Poros dan Air Permukaan Padang Lamun Bintan Timur. Jurnal Natur Indonesia, 5(2):139-144. 